\title{
KREASI, INOVASI, DAN PROMOSI BATIK "PE" (PITHECANTHROPUS ERECTUS) SEBAGAI CENDERA MATA WISATA ICONIC KABUPATEN NGAWI ${ }^{1}$
}

\author{
Rara Sugiarti, Margana, Nanang Setiyoko \\ Pusat Penelitian dan Pengembangan Pariwisata dan Budaya LPPM \\ Universitas Sebelas Maret \\ Email: rarasugiarti@staff.uns.ac.id
}

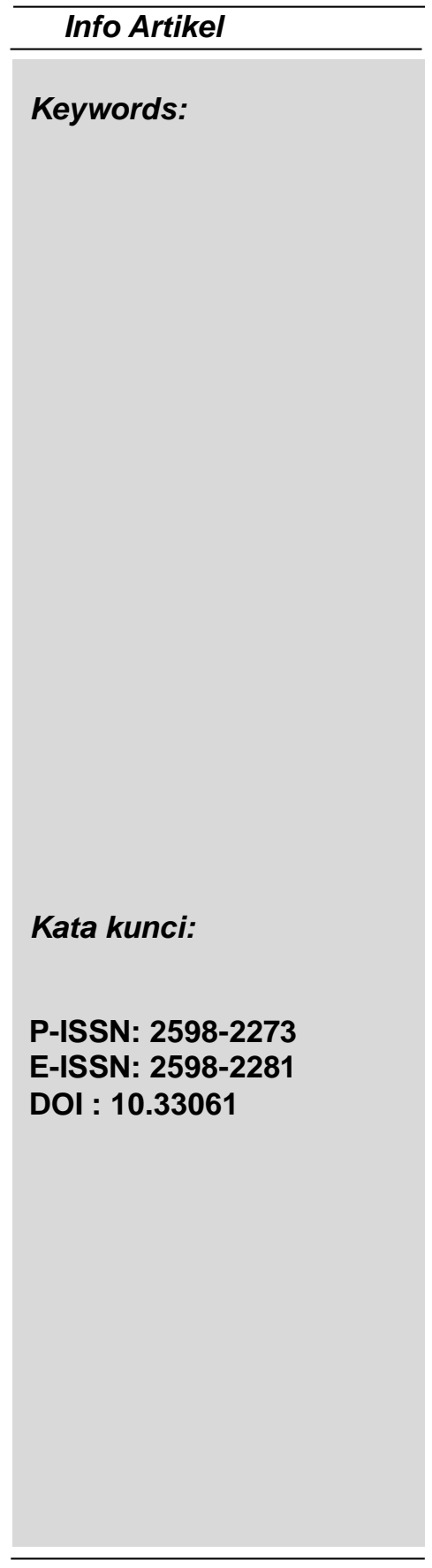

\begin{abstract}
UKM Batik Anisa encounters several problems including limited creativity and innovation to create new designs and iconic motifs that can represent regional characteristics, limited variations in batik color, limited market network, marketing strategies, and promotional media for batik products, limited knowledge about tourism and the important role of souvenir, and limited tools and materials that are relevant for initiating the development of new batik motif called pithecanthropus erectus (PE). This is innovative motif that has the potential to become iconic batik product of Ngawi. This activity aims to overcome problem faced by UKM Batik Anisa. Methods include counseling, discussing, training, and assisting. Results of the activity include innovations of new batik design and motifs (pithecanthropus erectus), variation of batik color through diverse combination of color, website to expand market networks, knowledge improvement concerning tourism and opportunities to create iconic souvenirs, and new tools to increase productivity of UKM Batik Anisa.
\end{abstract}

Keywords: batik; design; iconic; pithecanthropus erectus.

Abstrak
Batik Anisa menghadapi beberapa permasalahan yakni terbatasnya
kreativitas dan inovasi untuk membuat desain dan motif baru yang
iconic yang dapat merepresentasikan kekhasan daerah, terbatasnya
variasi warna batik yang dihasilkan oleh mitra, terbatasnya jejaring
pasar, strategi pemasaran serta media promosi bagi produk batik
yang dihasilkan oleh mitra, terbatasnya pengetahuan mitra tentang
pariwisata dan peran penting cendera mata khas daerah, serta
terbatasnya alat dan bahan yang relevan untuk menginisiasi
pengembangan batik pithecanthropus erectus (PE) sebagai desain
inovatif yang berpotensi menjadi produk batik yang iconic dari
Kabupaten Ngawi. Kegiatan ini bertujuan untuk mengatasi berbagai
permasalahan yang dihadapi oleh mitra tersebut. Metode kegiatan
terdiri atas penyuluhan, diskusi, pelatihan, dan pendampingan.
Hasil kegiatan ini adalah inovasi berupa berbagai desain dan motif
pithecanthropus erectus, variasi warna melalui kombinasi yang
lebih beragam, website untuk memperluas jejaring pasar,
peningkatan pemahaman mengenai pariwisata dan peluang
pengembangan cendera mata khas yang iconic, serta penambahan
alat-alat untuk meningkatkan produktivitas mitra.

Kata Kunci: batik; desain; ikonik; pithecanthropus erectus. 


\section{PENDAHULUAN}

Pariwisata dan seni kerajinan, termasuk batik, memiliki relasi simbiotik atau hubungan saling menguntungkan. Di satu sisi pariwisata dapat memperoleh manfaat dari seni kerajinan, termasuk batik, dalam hal mendiversifikasi daya tarik yang dapat dilihat, dilakukan, dan dibeli oleh wisatawan. Hal ini sesuai dengan salah satu konsep untuk menarik wisatawan, yakni "what to see, what to do, and what to buy" (Yoeti, 2002; Pitana \& Diarta, 2009). Batik sebagai salah satu seni kerajinan mampu merealisasikan konsep tersebut. Wisatawan yang datang ke sentra batik dapat melihat proses pembuatan batik, melakukan atau mempraktekkan sendiri cara membuat batik, serta dapat membeli berbagai macam produk batik yang dihasilkan oleh sentra batik tersebut sebagai cendera mata. Di sisi lain, batik mendapatkan manfaat dari pariwisata karena dengan adanya kegiatan wisata dan kunjungan wisatawan secara kontinyu, sentra-sentra batik mendapatkan perhatian, kepedulian, dan apresiasi, serta memperoleh manfaat ekonomi dari pariwisata. Wisatawan yang datang berpotensi membeli produk kerajinan batik yang dihasilkan oleh UKM atau yang dijual di lokasi-lokasi wisata. Dengan demikian batik akan bisa mempertahankan eksistensinya secara berkelanjutan.

Kabupaten Ngawi Propinsi Jawa Timur memiliki potensi batik yang cukup beragam yang merupakan salah satu produk andalan daerah (BAPPEDA Kabupaten Ngawi, 2016). Hal ini dapat dilihat dari berbagai jenis produk batik yang dihasilkan oleh UKM-UKM batik yang tersebar di wilayah tersebut (Sarungu, 2015). Potensi pengembangan batik di Kabupaten Ngawi juga telah dikaji dalam penelitian tentang batik Ngawi oleh Apriliani, Bubiarjo, \& Karsam. (2016). Di wilayah ini terdapat kelompokkelompok masyarakat yang sejak lama telah memproduksi batik secara tradisional dengan menggunakan teknik tulis. Kabupaten Ngawi mempunyai banyak pengrajin batik. Jumlah pengrajin batik di Kabupaten Ngawi mencapi lebih dari 1.350 orang yang sebagian besar terkonsentrasi di Desa Banyubiru (Prajogo, 2017). Meskipun belum optimal, seni kerajinan batik selama ini sudah memberi kontribusi kepada pengembangan perekonomian masyarakat setempat, utamanya dalam mengurangi pengangguran dan menambah penghasilan keluarga.

Namun demikian masyarakat batik Kabupaten Ngawi belum melihat adanya peluang untuk mengeksplorasi kearifan dan sumber daya lokal yang dapat disinergikan dengan batik dan pariwisata. Di Kabupaten Ngawi terdapat the early man site (situs manusia purba) yang dahulu pernah ditemukan oleh Eugene Dubois, seorang arkeolog dari Perancis pada tahun 1891 (Alink, Roebroeks, \& Simanjuntak, 2016). Penelitian tersebut berhasil menemukan fosil manusia purba yang disebut pithecantropus erectus atau PE. Potensi peninggalan prasejarah berupa situs manusia purba berjenis phitecantropus erectus (yang sering disebut dengan "PE") yang terdapat di daerah tersebut belum dilirik, digali dan dikembangkan untuk menjadi icon wilayah. Pengembangan motif batik berbasis local genius memiliki peluang untuk menampilkan identitas yang unique dan iconic yang mampu membangun destination image dan sekaligus menciptakan sense of place bagi suatu daerah wisata.

Dalam rangka mendukung hal tersebut kegiatan PKM ini memperkenalkan INOVASI desain dan motif batik yang memiliki kekhasan untuk mendorong mitra agar dapat bersaing dengan kompetitornya, dan mampu merebut pasar yang lebih luas. Upaya untuk memperkenalkan batik dengan desain dan motif baru yang inovatif ini dilatarbelakangi oleh adanya ketidaktersediaan motif yang khusus merepresentasikan karakter wilayah Kabupaten Ngawi. Motif yang diperkenalkan oleh Tim Pengabdi ini diberi nama motif batik Pithecanthropus Erectus atau batik PE, sebagai motif baru yang unique dan iconic yang diharapkan dapat menjadi ikon batik Ngawi. Motif PE ini disebut unik karena tidak ditemukan di daerah lain, terlebih di daerah yang tidak memiliki aset prasejarah sebagai muatan kearifan lokal. Demikian pula istilah iconic dalam kontek ini karena motif ini diharapkan dapat menjadi ciri, penanda atau identitas khas batik Ngawi. Istilah Pithecanthropus Erectus atau "PE" dipilih karena kata tersebut menampilkan istilah yang khusus, baru, aneh, dan bisa menimbulkan tanda tanya sehingga membuat orang ingin tahu. Pada umumnya keingintahuan seseorang terhadap sesuatu akan mendorong mereka untuk mencari hal tersebut sehingga dalam kontek ini istilah batik PE diharapkan menjadi daya tarik bagi para calon pembeli. 


\section{Permasalahan Mitra}

Kelompok Batik "Anisa" memiliki beberapa permasalahan baik dalam kontek hulu (produksi) maupun hilir (pasar). Pihak Pemerintah Kabupaten Ngawi yang diwakili oleh Dinas Koperasi, Usaha Mikro Kecil Menengah, dan Perindustrian, telah hadir untuk ikut memberikan solusi terhadap permasalahan tersebut. Namun kehadirannya lebih banyak diarahkan kepada pemberian bantuan teknik di bidang pewarnaan, utamanya pewarnaan alam. Bantuan teknis (technical assistance) selama ini masih terbatas dan belum menyentuh pada upaya mengeksplorasi bersama sumber daya dan kearifan lokal yang dapat dikembangkan untuk menjadi motif batik yang unique dan iconic untuk mewakili Kabupaten Ngawi.

Oleh karena itu Tim PKM melihat sisi lain dari permasalahan yang dihadapi oleh mitra, dengan mengutamakan pada upaya membangun sinergi antara pariwisata dengan seni kerajinan sebagai daya tarik wisata. Beberapa permasalahan yang telah diidentifikasi oleh tim pengabdi bersama dengan mitra (Batik "Anisa") adalah sebagai berikut.

1. Terbatasnya kreativitas dan inovasi untuk membuat desain dan motif baru berupa batik yang unique dan iconic berupa motif pithecanthropus erectus yang dapat menjadi ciri khusus produk yang dihasilkan oleh mitra dan sekaligus menjadi identitas khas daerah.

2. Terbatasnya ragam motif batik unique \& iconic dan desain batik yang inovatif, yakni batik pithecanthropus erectus, yang hingga saat ini belum pernah dipikirkan oleh para stakeholder batik, termasuk para designer batik maupun para produsen batik di Kabupaten Ngawi.

3. Terbatasnya variasi warna batik yang dihasilkan oleh mitra, khususnya dalam hal mengkombinasikan atau memadukan warna dalam satu kesatuan produk batik.

4. Terbatasnya jejaring pasar (market network) dan media promosi bagi produk batik yang dihasilkan oleh mitra.

5. Terbatasnya pengetahuan mitra tentang pariwisata, khususnya dalam menangkap peluang melalui eksplorasi cendera mata wisata yang khas berupa seni kerajinan batik lokal yang unique dan iconic.

6. Terbatasnya alat dan bahan yang relevan untuk menginisiasi pengembangan batik pithecanthropus erectus (PE) sebagai desain inovatif yang berpotensi menjadi produk batik yang unique dan iconic dari wilayah Kabupaten Ngawi.

\section{METODE KEGIATAN}

Program ini dilaksanakan di lokasi mitra, yakni UKM Batik Anisa yang terletak di Desa Banyubiru Kecamatan Widodaren Kabupaten Ngawi Propinsi Jawa Timur. Jangka waktu pelaksanaan kegiatan selama delapan bulan, mulai April 2019 sampai dengan November 2019. Mitra yang menjadi peserta dalam program ini adalah Batik Anisa yang memiliki lima orang pengrajin tetap. Berdasarkan pada permasalahan yang telah diidentifikasi bersama dengan mitra maka metode yang diterapkan dalam program kemitraan masyarakat ini adalah penyuluhan, diskusi dan tanya jawab, pelatihan, dan pendampingan.

1. Penyuluhan dilaksanakan untuk memberikan pengetahuan dan pemahaman serta memperluas wawasan mitra mengenai strategi untuk mensinergikan batik dengan kearifan dan sumber daya lokal, seperti Pithecanthropus Erectus (PE) serta pariwisata. Penyuluhan juga ditujukan untuk memberikan wawasan mengenai strategi promosi dan pemasaran produk batik yang dihasilkan mitra.

2. Diskusi dan tanya jawab diarahkan untuk memberikan peluang kepada mitra dalam mengekspresikan gagasan, ide, rancangan motif dan desain yang diinginkan berkaitan dengan batik Pithecanthropus Erectus (PE).

3. Pelatihan dilaksanakan untuk memberikan materi kepada mitra mengenai desain dan motif batik Pithecanthropus Erectus (PE) untuk menghasilkan produk sesuai dengan tujuan dan output yang diharapkan. 
4. Pendampingan

Pendampingan dilaksanakan untuk memberikan bimbingan dan arahan kepada mitra dalam rangka meningkatkan diversifikasi motif dan desain batik yang diproduksi oleh mitra dengan menintegrasikan kearifan dan sumber daya lokal seperti Pithecanthropus Erectus (PE).

5. Penambahan Alat

Penambahan alat dilaksanakan untuk membantu mittra mengembangkan kapasitas produksi serta meningkatkan kualitas pewarnaan batik yang dihasilkan. Beberapa alat yang ditambakan meliputi kompor, ember, gawangan, timbangan digital, dan meja desain.

\section{PEMBAHASAN}

Hasil pelaksanaan program mengacu pada permasalahan yang dihadapi oleh mitra, yakni terbatasnya kreativitas dan inovasi untuk membuat desain baru yang dapat menjadi ciri khusus produk yang dihasilkan oleh mitra, terbatasnya ragam motif batik unique dan iconic dan desain batik yang inovatif, yakni batik Pithecanthropus Erectus (PE), terbatasnya variasi warna batik yang dihasilkan oleh mitra, terbatasnya jejaring pasar (market network) dan media promosi bagi produk batik yang dihasilkan oleh mitra, terbatasnya pengetahuan mitra tentang pariwisata dan cendera mata, dan terbatasnya alat yang relevan untuk mengembangkan batik pithecanthropus erectus. Berdasarkan beberapa permasalahan tersebut dilaksanakan sub kegiatan sebagai berikut.

\section{Pengembangan Desain dan Motif Batik Pithecanthropus Erectus}

Dalam kegiatan pendampingan ini tim pengabdi memberikan pemahaman mengenai perbedaan antara desain dan motif batik. Desain batik mengacu kepada pembuatan pola untuk seluruh lembar kain yang akan dibatik. Sedangkan motif batik mengacu kepada gambar yang akan diaplikasikan di atas kain yang akan dibatik. Desain yang dipraktekkan oleh mitra meliputi desain run-stop, desain fully-bloked, desain "pagi-sore", dan desain batik gender.

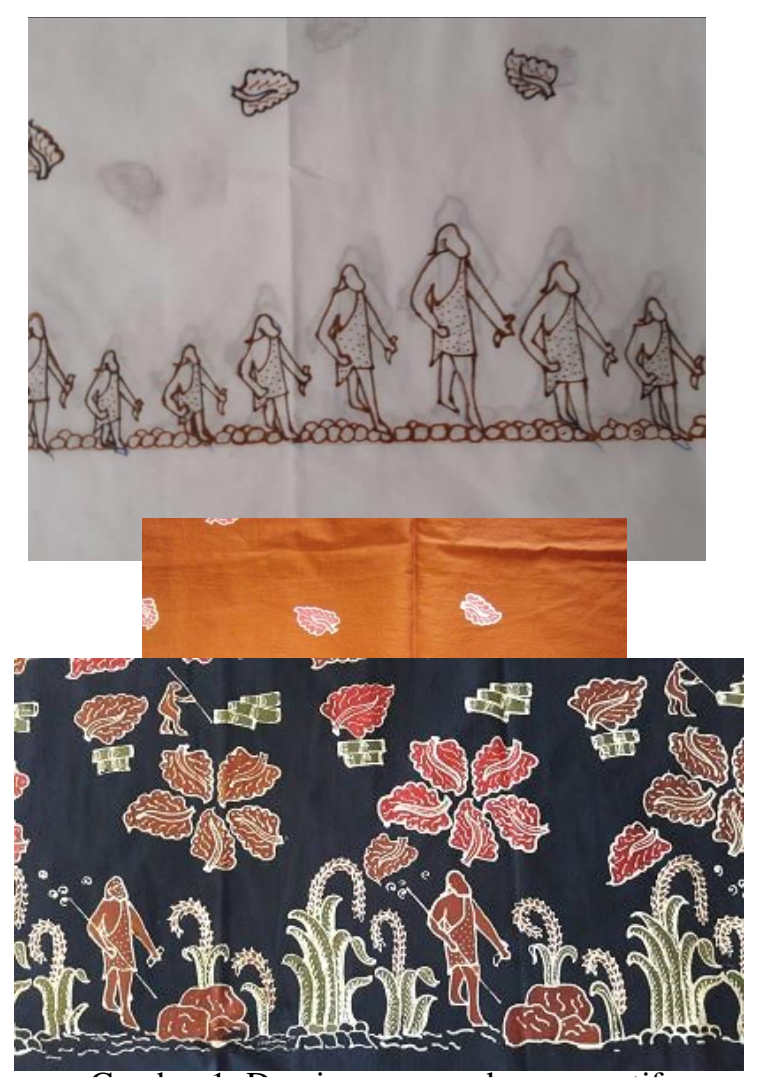

Gambar 2: Desain run-stop berulang dengan motif Pithecanthropus Erectus (PE). 


\section{Pengembangan Warna Batik Pithecanthropus Erectus}

Dalam pendampingan pewarnaan batik tim pengabdi memberikan pengarahan untuk menggunakan warna campuran atau kombinasi. Untuk membuat kombinasi warna yang ajeg atau konsisten tim memberikan bantuan peralatan berupa timbangan digital agar komposisi warna yang akan dibuat memiliki presisi yang lebih akurat untuk diulang. Sebelum ada kegiatan pengabdian ini mitra hanya mengandalkan pada perkiraan dengan takaran manual seperti sendok. Namun dengan adanya timbangan digital komposisi warna menjadi lebih ajeg dan tepat.

\section{Perluasan Jejaring Pasar dan Pengembangan Promosi}

Selama ini jangkauan dan jejaring pemasaran batik yang diproduksi oleh UKM Batik Anisa masih sangat terbatas. Dengan adanya pendampingan melalui kegiatan PKM ini UKM Batik Anisa telah diberi bekal wawasan untuk membangun jejaring dengan berbagai pihak terkait seperti sekolahsekolah, kantor-kantor pemerintah maupun swasta, serta outlet lain seperti pameran rutin yang diselenggarakan oleh Pemerintah Kabupaten Ngawi dalam rangka hari jadi dan event lainnya. Untuk mempromosikan produk-produk yang dihasilkan oleh Batik Anisa telah dibuat website promosi di laman: batikanisa.com. Pembuatan website UKM Batik Anisa baru dilakukan setelah adanya pendampingan dari Tim Pengabdi PKM dari Pusat Penelitian dan Pengembangan Pariwisata dan Budaya LPPM Universitas Sebelas Maret. Fungsi website utamanya adalah sebagai etalase untuk memperkenalkan dan memamerkan produk-produk batik yang dihasilkan oleh UKM Batik Anisa, utamanya batik yang bermotif Phitecanthropus Erectus.

\section{Perluasan wawasan mengenai sinergi antara batik dan pariwisata}

Dalam berbagai kontek, batik dan pariwisata memiliki hubungan yang simbiotis. Di satu sisi, pariwisata memberi kontribusi besar kepada pengembangan batik. Berbagai daerah tujuan wisata telah memanfaatkan batik sebagai cendera mata sehingga penjualan produk batik meningkat. Di sisi lain, batik juga memberi kontribusi kepada pariwisata. Proses kegiatan membatik telah mendukung diversifikasi atraksi atau daya tarik wisata. Banyak wisatawan tertarik untuk mengunjungi sentra pembuatan batik dan mencoba proses pembuatan batik. Pemanfaatan batik sebagai cendera mata juga meningkatkan nilai ekonomis atau nilai komersial dari batik, terlebih apabila batik yang diproduksi memiliki keunikan atau ciri khas daerah. Masyarakat pada akhirnya memahami bahwa pembuatan cendera mata khas daerah memberikan banyak manfaat. Pertama, cendera mata khas dapat menjadi icon suatu daerah. Cendera mata yang iconic memiliki kekuatan untuk mendatangkan wisatawan untuk berkunjung ke daerah yang memiliki cendera mata unik tersebut. Dengan demikian hal ini dapat memberikan dampak ganda seperti pendapatan para penjual dan pembuat cendera mata. Cendera mata dapat menjadi sarana yang sangat efektif untuk mengenalkan daerah tujuan wisata. Cendera mata berupa batik bermotif Pithecanthropus Erectus memiliki daya tarik tersendiri.

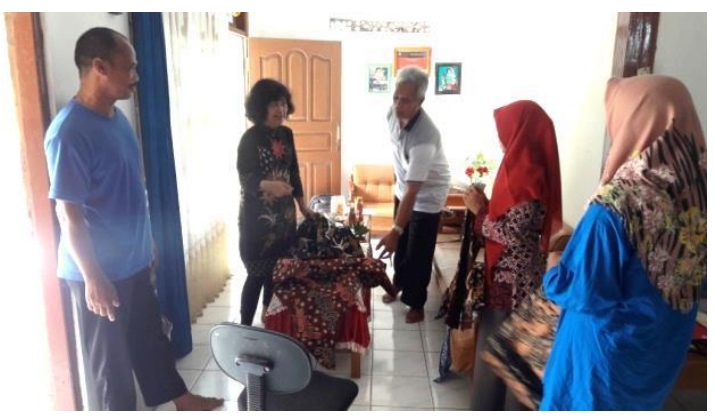

Gambar 3: Kegiatan Pendampingan.

\section{Peningkatan Peralatan}

Selama proses pendampingan beberapa alat diberikan kepada mitra sebagai bantuan untuk meningkatkan produktivitas mitra, baik dalam hal kuantitas maupun kualitas. Alat-alat tersebut antara lain adalah timbangan digital, meja gambar, kompor, gawangan, canting, bak lorot, ember plastik. Keberadaan alat-alat tambahan tersebut telah memberikan kontribusi kepada mitra dalam meningkatkan kapasitas produksinya. 


\section{PENUTUP}

\section{Simpulan}

Dalam kurun waktu 8 bulan kegiatan PKM ini telah memberikan bekal kepada mitra untuk meningkatkan kreativitas dan inovasi dalam rangka membuat desain dan motif baru yakni motif pithecanthropus erectus. Desain dan motif tersebut menjadi batik yang unique dan iconic yang dapat menjadi ciri khusus produk yang dihasilkan oleh mitra dan sekaligus menjadi identitas khas daerah Kabupaten Ngawi. Kegiatan PKM ini juga telah memberikan pengetahuan kepada mitra untuk mendiversifikasi warna, khususnya dalam hal mengkombinasikan atau memadukan warna dalam satu kesatuan produk batik pithecanthropus erectus. Pengembangan promosi dan pemasaran dilakukan dengan membuat website yang berfungsi sebagai etalase atau tempat memamerkan produk yang dihasilkan oleh mitra. Selain melalui pembuatan website, pengembangan jejaring pasar (market network) dan media promosi dilakukan melalui berbagai media sosial seperti facebook, instagram, dan WhatsApp. Dalam rangka mengembangkan batik pithecanthropus erectus sebagai cendera mata wisata iconic Kabupaten Ngawi mitra telah diberi pemahaman dan pengetahuan mengenai peran cendera mata dalam pariwisata sehingga mereka dapat memanfaatkan peluang usaha pengembangan cendera mata berbasis batik pithecanthropus erectus. Penambahan alat untuk mendukung proses pembuatan batik pithecanthropus erectus menjadi salah satu faktor yang memberi kontribusi terhadap pengembangan usaha mitra dalam pembuatan batik.

\section{Saran}

Dalam rangka mempertahankan keberlanjutan usaha serta dalam upaya mengembangkan bisnis pembuatan batik, mitra sebaiknya melakukan beberapa hal, yakni: berkoordinasi dengan pemerintah daerah setempat untuk mendapatkan peluang promosi dan pendampingan usaha, merintis kerjasama pemasaran dengan berbagai instansi, sekolah, dan organisasi masyarakat, meningkatkan pengetahuan mengenai tren pasar melalui website (internet) dan berbagai media sosial seperti facebook, whatshap, dan instagram.

\section{Ucapan Terima Kasih}

Tim Pengabdi mengucapkan terima kasih kepada KEMRISTEKDIKTI yang telah memfasilitasi dana kegiatan pengabdian melalui Program Kemitraan Masyarakat Tahun Anggaran 2019 dengan Nomor Kontrak: 720/UN27.21/PM/2019.

\section{REFERENSI}

Alink G, Roebroeks W, and Simanjuntak T. 2016. The Homo erectus site of Trinil: Past, Present and Future of a historic place. AMERTA Jurnal Penelitian dan Pengembangan Arkeologi. 34(2): 99114.

Apriliani IM, Bubiarjo H and Karsam. 2016. Perancangan motif batik tulis ikon Kabupaten Ngawi sebagai media promosi dalam menunjang industri kreatif. Art Nouveau. 5(2): 1-10.

BAPPEDA Kabupaten Ngawi. 2016. Profil Investasi Daerah Kabupaten Ngawi.

Pitana, IG dan Diarta IKS. 2009. Pengantar IImu Pariwisata. Yogyakarta: Penerbit Andi.

Prajogo U. 2017. Penguatan industri batik nasional dalam menghadapi ACFTA dan MEA. Makalah Seminar Nasional "Peningkatan Ketahanan Ekonomi Nasional Dalam Rangka Menghadapi Persaingan Global. Malang: FEB Unikama.

Sarungu, dkk. 2015. Strategi Pengembangan Ekonomi Lokal Berbasis Potensi Industri Kreatif Seni Batik di Kabupaten Ngawi. Surakarta: Universitas Sebelas Maret.

Yoeti, O. A. 2002. Pengantar IImu Pariwisata (Edisi Revisi). Bandung: Angkasa. 